\title{
Què significa la música? Una aproximació a la dimensió comunicativa de l'experiència musical ${ }^{1}$
}

\begin{abstract}
Alberto Cabedo Mas (cabedoa@uji.es) Universitat Jaume I

La necesidad de crear y escuchar música es el rasgo más misterioso y admirable de la humanidad. Es la forma de poner en contacto el mundo real con el mundo de los recuerdos, con la magia, las emociones y los sueños (Hormigos Ruiz, 2008: 20).
\end{abstract}

\section{Introducció}

Les persones tendim fàcilment a naturalitzar el fet que en qualsevol context geogràfic a què fem al-lusió, l'home sent la necessitat de ser partícip de fets artístics. Assumim com a normal que, diàriament, milions de persones escolten música, llegeixen un llibre o observen o pinten un quadre (Fischer, 2001: 10). Podríem pensar que el fet artístic únicament forma part de la variable de l'oci d'una persona, i que, d'aquesta manera, resulta un fet a primera vista improductiu. Però en aquest cas, es fa un tant peculiar el fet que les nostres vides estiguen pràcticament envoltades d'art. «La música está por doquier, es omnipresente. Su espacio natural no se limita ni mucho menos a las convencionales salas de conciertos. Su presencia invade nuestras casas, los largos corredores del metro, el interior de nuestro automóvil, las iglesias, los grandes almacenes...» (Martí i Pérez, 2000: 13).

Per què, doncs, un fet que en principi puga parèixer tan banal, com l'activitat ociosa d'escoltar música, pot de vegades estar tan present en les nostres vides?

En el següent article pretenc fer un recorregut pels corrents de pensament més rellevants que han abordat la dimensió social del fenomen musical. Concretament, amb això busque il·lustrar arguments en referència a la música en la seua dimensió comunicativa, i la influència que aquesta puga tenir en la construcció social de col·lectius. Per això, exploraré algunes de les principals tendències que teoritzen sobre els processos de significació derivats del fet musical. Finalment, defensaré la influència de la dimensió relacional i colllectiva de l'ésser humà per tal de transmetre i entendre el fenomen de la música. Des d'aquestes mirades defensaré la noció de la música com un element important en la construcció ideològica i identitària de persones i pobles.

${ }^{1}$ Traducció del castellà de Cristina Martínez Ortuño (UJI). 


\section{La dimensió comunicativa de la música: música, llenguatge i significat}

Si ens aturem a pensar detingudament en la quantitat de vegades que al llarg d'un dia atenem, conscients o no, al fenomen musical, ens adonarem que, efectivament, la música no és en absolut aliena a les nostres realitats. La música està contínuament present en les nostres vides, i nosaltres, com a productors o com a receptors, no som de cap manera aliens a aquest fet. Cantussegem o tarallegem una cançoneta, o tenim en la ment una melodia que durant diversos dies no ens podem treure del cap. Escoltem músiques en concerts, però també en enregistraments i en mitjans audiovisuals. Al seu torn, sense presumir de grans coneixements musicals, podem asseverar quines músiques ens resulten agradables i quines no; fins i tot podem destacar amb quin estil musical ens sentim més identificats. Aquests fets ens converteixen indefectiblement en subjectes musicals. Sovint creiem que som totalment incapaços per al fet musical, i que manquem per complet de la coneguda oïda musical. No obstant això, s'encerta en pensar que si podem discutir de manera argumentada quina música ens agrada, és perquè necessàriament tenim un cert criteri musical que ens converteix en susceptibles a la dimensió expressiva de la música. Som, per tant, subjectes amb determinades destreses musicals.

Podem assegurar que la gran majoria d'éssers humans tenim capacitats naturals per a reaccionar davant d'un fenomen musical. Sens dubte, la manera en què actuem davant la música és certament multidimensional i, fins i tot, particular. Tenim centenars de maneres diferents d'afrontar un fet musical i, al seu torn, cada persona respon de formes molt diverses. Però en essència, aquesta capacitat de reacció davant del fet musical que posseeixen les persones és un factor decisiu perquè la música siga veritablement transcendental en les nostres vides. Sentim enyorança quan escoltem les cançons d'aquells meravellosos anys passats, i també quan escoltem aquella cançó que associàvem amb aquell company estimat que ja no hi és. Riem quan sona la música d'aquest fragment tan còmic de la pellícula amb la qual vam passar bons moments, i ens emocionem en sentir les notes de l'escena final d'aquell musical que tant ens va agradar. Sentim complicitat amb el nostre company quan sona la cançó del grup musical que compartim com a favorit, ens quadrem davant el nostre himne, però ens enfadem quan escoltem la música representativa de l'equip de futbol que ens va vèncer en l'últim partit.

Efectivament, tenim aptituds per a reaccionar davant de la música, encara que en moltes ocasions ni tan sols en siguem conscients. En definitiva, aquesta reacció davant del fenomen musical rau en la majoria d'ocasions en la manera com les persones perceben, consumeixen o gaudeixen de la música. Aquest fet anima a centrar interès i atenció en el procés de l'escolta musical.

\subsection{Escolta musical: connexió entre subjecte i música}

Les persones no sempre escoltem la música de la mateixa manera. La recepció de material sonor variarà en funció del procés auditiu que en fem, i aquest, al seu torn, condicionarà la resposta i la reacció davant de cada música. És complicat tractar de classificar els diversos tipus d'escolta i, sens dubte, qualsevol dissociació dels factors que 
condicionen l'audició musical és parcial i incompleta. En qualsevol cas, en l'anàlisi del discurs musical com a factor de comunicació resulta interessant tractar d'aclarir el concepte d'escolta musical. Per a això, ens acostem a les definicions dels diversos tipus d'escolta que el compositor Aaron Copland (1988) presenta.

La manera d'afrontar el fenomen musical comporta en molts casos una escolta passiva. En moltes ocasions, sentim la música, ni tan sols l'escoltem, o apliquem una manera d'enfrontar-nos-hi que respon principalment a allò que Copland (1988: 17) anomena el pla sensual.

El modo más sencillo de escuchar la música es escuchar por el puro placer que produce el sonido musical mismo. Ése es el plano sensual. Es el plano en el que oímos la música sin pensar en ella ni examinarla en modo alguno. [...] El mero atractivo sonoro de la música engendra una especie de estado de ánimo tonto pero placentero.

Aquesta capacitat de la música de produir una sensació de benestar, de vegades fins i tot anestèsica, fa que, segons l'autor, l'atmosfera d'un lloc determinat canviï completament únicament fent sonar unes lleugeres notes. Aquest efecte converteix el fenomen musical en un agent poderós i misteriós. Podem emprar l'efecte plaent derivat del fet musical com a consol o evasió. Fins i tot, sense arribar a prestar massa atenció a les característiques purament musicals de l'obra que s'escolta, aquesta ens pot portar a un estat de somni, desconnectat de la realitat (Copland, 1988: 17-18).

Si centrem ara la nostra atenció en el mateix fenomen musical, ens adonem que existeix una determinada producció - o reproducció- de música que pot tenir com a finalitat principal generar en l'oient aquest determinat tipus d'escolta. Aquí rauria la base dels eslògans i de les músiques comercials que semblen buscar el foment del consumisme en el receptor. També s'inclouen totes aquelles músiques ambientals que aparentment no pretenen tenir altra funció que ser part d'una millora estètica d'un producte, situació o esdeveniment determinat. Fer que sone música omple el buit incòmode que produeix el silenci, oculta els sorolls ambientals, i, si aquesta és estèticament bella per a la nostra concepció, desperta en l'oient una millora en l'estat de benestar. Fem referència a les anomenades músiques de fons - background music - que ocupen espais públics com ara comerços, botigues, magatzems, gimnasos, ascensors, etc.

El segon dels plans d'escolta fa referència a la capacitat expressiva de la música. Fa referència, per tant, al pla expressiu. És probablement el nivell d'escolta més controvertit, ja que desencadena fàcilment una reflexió sobre la capacitat de la música de generar certs sentiments o expressions en l'oient (Copland, 1988: 18-19).

Bien sabe Dios cuán difícil es precisar lo que quiere decir una pieza de música, precisarlo de una manera terminante, precisarlo, en fin, de modo que todos queden satisfechos de nuestra explicación. Más eso no debe llevarnos al otro extremo, al de negar a la música el derecho a ser "expresiva".

Resulta extremadament difícil tractar de descriure amb paraules què vol dir-nos una música en particular. Més encara quan es busca transmetre què em diu, expressa o suggereix 
aquesta música a mi en comparació amb allò que suscita en altres persones. Perquè no dubtem de la capacitat de la música d'evocar alegria, tristesa, vivacitat o fins i tot d'illlustrar un ocell, un tren o una tempesta. Alguns podrien opinar que com més fàcil siga connectar una música amb el llenguatge parlat, més expressiva serà.

Siga com siga, estem d'acord amb Copland (1988: 21) quan afirma que «la música té en realitat un significat expressiu, però no podem dir en unes quantes paraules quin és aquest significat». Tanmateix, assumim que aquesta expressió no ha de seguir un únic patró vàlid per a totes les persones, i hi ha múltiples factors que poden determinar l'audició musical.

L'últim dels plans a què l'autor fa referència és el pla purament musical. Aquest al-ludeix a l'escolta del material estrictament musical que una peça o fragment posseeixi. En una metafòrica adaptació actual podem caracteritzar aquest concepte de la següent manera (Malbrán, 1997: 44):

En la escucha profunda, esto es en la audición comprensiva de la música en tiempo real, nuestra mente opera como un veloz procesador on line. Con él vamos incorporando emociones por el placer de la escucha y pensamientos en intenso avance y retroceso en base a relaciones sucesivas y simultáneas.

La quantitat d'informació que l'oient rep d'aquest pla varia segons la seua experiència prèvia amb aquesta música determinada. La destresa en un tipus determinat de música acreix la focalització de l'oient cap a aquest model particular d'escolta; per contra, un oient inexpert en un determinat estil musical rep una informació pràcticament nímia d'aquest pla de l'escolta.

Un cop més, es ressalta la limitació que suposa tractar de diferenciar diversos plans d'escolta. No obstant això, coincidim de nou amb Copland (1988: 22) en advertir que la recepció de la música no es fa de manera dissociada, sinó que és un mecanisme més global. «En realitat, mai s'escolta en aquest pla o en aquell altre. Allò que es fa és relacionar-los entre si i escoltar de les tres maneres alhora. Això no exigeix cap esforç, ja que es fa instintivament».

Sembla que aquesta afirmació contradiu la reflexió sobre la falta d'informació obtinguda per l'oient inexpert en escoltar en el pla estrictament musical. Si bé la recepció d'elements purament musicals varia, en efecte, en funció de l'experiència prèvia que l'oient tinga amb un determinat estil musical, pràcticament totes les persones tenim capacitat per a rebre algun tipus d'informació de tipus essencialment musical, partint de la base que considerem allò que escoltem com a música. Si bé la nostra imperícia en un determinat gènere musical dificultarà la comprensió de materials sonors propis d'aquest gènere, tendirem a relacionarlo amb elements musicals característics de l'estil musical en el qual som destres o ens resulta familiar d'alguna manera.

Efectivament, les persones escoltem la música de maneres diferents. La recepció d'informació que el fenomen musical aporta, així com la reacció que les persones tenim davant del material sonor, no segueix un patró o esquema rígid de comportament, sinó que varia en funció de particularitats personals i culturals. Però aquesta informació possibilita que la música siga un element comunicatiu per a les persones i que, per tant, tota música, i no només aquella a la qual se li annexa un text, siga portadora de significat. 


\subsection{Formalisme, referencialisme y expressionisme com a punts de vista complementaris sobre el significat musical}

La música comunica, és un mitjà a través del qual les persones poden expressar-se, transmetre i rebre missatges que, tot i no formar part necessàriament del llenguatge convencional, són portadors de significats.

La capacitat de la música de ser portadora de significats ha suscitat innombrables debats $\mathrm{i}$ estudis que, des de perspectives molt diverses, han tractat d'analitzar el procés comunicatiu que es produeix a través del fenomen musical. En aquest espai és interessant fer alllusió a diferents punts de vista sobre els significats continguts en la música i com descodifiquen les persones els missatges que provenen de discursos musicals. En emprar el terme discurs, es fa referència a la seua accepció quotidiana, obviant les seues connotacions més tècniques. Discurs s'utilitzarà com un terme genèric d'intercanvi de significats, que incorporarà aquells més trivials o profunds, els obvis i els recòndits, els nous i els vells, els tècnics i els vernacles (Swanwick, 1999: 2).

Efectivament, les maneres en què s'ha entès el significat de la música són molt diverses. Probablement, la raó fonamental rau en el fet que la transferència d'informació a través de la música es produeix d'una forma diferent a la del llenguatge convencional. Per açò, la música és un element comunicatiu propi, i la seua funció comunicativa ha estat analitzada per músics intèrprets, compositors, psicòlegs, estetes, filòsofs i altres teòrics que han focalitzat el seu interès en aquest fenomen. Tot i que, com diem, els enfocaments sobre què i com es comunica a través de la música són nombrosos i, de vegades, veritablement dispars, la tesi que la música té, en certa mesura, significats és defensada per la majoria d'estudiosos. Aquesta argumentació ha estat sustentada, entre d'altres, a través de les teories del compositor i filòsof Leonard B. Meyer (2001) qui, en el seu tractat La emoción y el significado en la música sobre la psicologia de la percepció musical, realitza un estudi exhaustiu sobre la naturalesa de l'experiència musical. Meyer (2001: 26), que recull en la seua obra les experiències d'autors com Cazden, Farnsworth i Langer, analitza les diferents perspectives del funcionament i mecanismes de la ment per tal de percebre i entendre la música, partint de la idea que, efectivament, la música és portadora de significació (Meyer, 2001: 23).

Los compositores e intérpretes de todas las culturas, los teóricos de las diversas escuelas y estilos, los especialistas en estética y los críticos de tendencias muy diferentes están de acuerdo en que la música posee un significado y en que dicho significado se comunica de algún modo a los que toman parte en ella y a los oyentes. Esto es algo que, al menos, podemos dar por sentado.

Podem dir que quan escoltem música rebem una determinada informació i aquesta és la mateixa que perceben totes les persones? Els éssers humans no entenem la música seguint un esquema o patró absolut de descodificació, sinó que la informació que rebem varia en funció de múltiples factors, tant personals com culturals. Aquest fet ha portat a diversos autors a qüestionar-se la capacitat de la música de significar. Paul Hindemith i Ígor Stravinski, per citar dos compositors de reconegut prestigi, van reflexionar sobre la significació en la música. Hindemith defensava que la música no té la capacitat d'expressar 
els sentiments del compositor, mentre que Stravinski enunciava que la música manca de poder per a expressar res en absolut (Swanwick, 2001: 13) -el terme expressar s'entén en aquest context com comunicar.

Aquesta afirmació del mestre Stravinski pot resultar curiosa, i més encara quan tantes persones s'han delectat i han reconegut el valor expressiu de La consagració de la primavera o L'ocell de foc. Això ens porta necessàriament a tractar de concretar què s'entén per comunicar a través de la música. El mestre Stravinski, per exemple, aborda l'ús compositiu de la dissonància dictant la lliçó sobre les seues idees en la creació musical (Stravinski, 2006: 38-39).

La disonancia, en este caso, tiene el valor de la alusión. Todo esto supone un estilo en el que el uso de la disonancia estipula la necesidad de una resolución. Pero nada nos obliga a buscar constantemente la satisfacción en el reposo. [...] La disonancia no es ya un factor de desorden, como la consonancia no es, tampoco, una garantía de seguridad.

S'assumeix en aquestes afirmacions la capacitat de suggestió que, almenys en la música occidental dels segles XVIII i XIX, implica la dissonància. Sembla doncs que Stravinski explica que una dissonància indica una inestabilitat $\mathrm{i}$, al seu torn, requereix d'una consegüent consonància, que aporte la desitjada distensió. En aquest cas, podrem afirmar que la dissonància, dins d'un context d'anàlisi determinat, porta una informació implícita que, sota uns determinats pressupostos, pot ser entesa com a significat. Així mateix, Stravinski descartava la necessitat que actualment la dissonància implique una posterior consonància, per a diferenciar clarament la música del passat de la tradició contemporània —en la veu del mestre, l'emancipació de la dissonància. Efectivament, aquesta afirmació reforça la tesi que històricament s'havien atorgat unes determinades connotacions significatives a la dissonància que el progrés musical necessita relegar, per tal de construir una subsegüent assignació de significat que es consolidarà amb l'atribució de valor.

Per això, el debat se centra principalment en què i com es comunica a través de la música. L'anàlisi de quines implicacions comporta la transmissió de significats musicals, i de mitjançant quins processos la música es converteix en un element comunicatiu, resulta un fenomen complex, perquè allò que la música expressa, en la majoria d'ocasions, és difícil reflectir-ho en paraules; els missatges tampoc es produeixen d'una única manera ni són unidireccionals, sinó que cada persona pot entendre de diverses maneres el mateix fragment musical, en funció de la naturalesa del referent que s'associa a una música.

Existeixen clares divisions d'opinió entre els estudiosos de la significació musical. Alguns teòrics defensen la tesi que els significats musicals al-ludeixen únicament al context de la música mateixa: aquests són coneguts com absolutistes. D’altra banda, molts estudiosos afirmen que la música, a més d'aquests significats exclusivament musicals, té la capacitat de referir significació més enllà de la música mateixa: aquests, que són considerats referencialistes, defensen que «la música comunica també significats que d'alguna manera es refereixen al món extramusical dels conceptes, de les accions, dels estats emocionals i del caràcter» (Meyer, 2001: 23).

Ambdues postures, segons l'opinió de Meyer, no són excloents, sinó més aviat complementàries, ja que tots dos significats coexisteixen i fins i tot es complementen 
en una mateixa peça musical. La simultaneïtat d'ambdues significacions pot afavorir la vivència d'una experiència musical molt més completa.

No hem de confondre aquest debat amb el dels corrents d'estètica musical que defensen posicions com la formalista i l'expressionista. La naturalesa de l'experiència musical comporta una determinada significació en l'oient. Però aquesta percepció i comprensió pot ser fruit d'una resposta enterament intel-lectual, resultat de les relacions intramusicals, tal com defensen els formalistes, o poden adquirir la capacitat de despertar una reacció principalment emocional, com argumenten els expressionistes (Meyer, 2001: 24-25). Per bé que tot referencialista serà principalment expressionista, no hem d'assumir el cas invers, ja que la resposta expressionista pot ser argumentada des d'una naturalesa bàsicament absolutista. Potser, com Meyer (2001: 25) indica, la no diferenciació entre aquestes postures és el que porta a Stravinski, des de la seua posició formalista, a defensar la incapacitat d'expressió de la música, assumint que aquesta deriva únicament del significat referencial.

Una visió formalista del significat musical caracteritza la música com un art enterament autònom, sense cap significat més enllà de la música en si mateixa. Aquesta postura, amb la qual naturalment concorden Stravinski i Hindemith, va ser defensada principalment pel teòric Eduard Hanslick (1824-1904). Hanslick argumenta que la música és fonamentalment autoreferencial, ja que tant el contingut significatiu com el seu valor resideixen en el moviment de les formes tonals. Així mateix, Hanslick - i també Nietzsche- emfatitzen que la música no té capacitat per a contenir un significat definit. La dimensió estètica de la música resideix, des d'aquesta perspectiva, en els conceptes i accepcions de forma $\mathrm{i}$ tema, i per tant, la bellesa del fenomen musical en depèn. «Allò bell no té cap finalitat en absolut, perquè és pura forma, la qual, encara que pot ser utilitzada per a les finalitats més diverses, segons el contingut amb què s'omple, no té cap altra finalitat que ella mateixa» (Hanslick, 1957: 5).

Una postura oposada a la formalista és la mirada referencialista, defensada, entre d'altres, per Deryck Cooke (1919-1976). Per als referencialistes, la música té la capacitat de representar objectes o material extramusical, bé siga a través de la seua imitació directa, d'una imitació aproximativa o mitjançant la suggestió o simbolització d'aquests objectes o materials. Per aquesta raó, l'anàlisi dels elements musicals - sons, intervals, harmonies, etc. - proveeix d'informació sobre la forma que la música expressa les emocions. Afirmacions com «la nostra tercera major s'ha establert naturalment per sí mateixa com una expressió de plaer o d'alegria» (Cooke, 1959: 55) demostren que la música és un llenguatge que, tot i diferir en el contingut, té una estructura i un fons semblants al llenguatge convencional. Per tant, es pot establir un llenguatge musical d'una manera similar al llenguatge convencional, de tal forma que la música s'entenga com un llenguatge de comunicació d'emocions i sentiments. Des d'aquesta perspectiva, el compositor té la capacitat de transmetre a l'oient una sèrie d'informació, bé siga objectiva o purament emocional, ja que la música - el seu significat - expressa directament un referent determinat segons un patró natural d'assumpció d'elements sonors regit per unes regles sintàctiques (Marrades Millet, 2000: 6).

Hay un orden objetivo en la experiencia emocional que puede ser representado en la música mediante el establecimiento de una relación figurativa entre elementos del lenguaje musical y 
elementos del mundo de las emociones. Y puede serlo, en virtud de que los elementos musicales representan naturalmente sus objetos.

Una visió referencialista assumeix que la música és expressiva, sempre des d'una perspectiva d'anàlisi de les regles segons els patrons concrets de la música clàssica occidental.

El tercer dels punts de vista sobre el significat dels discursos musicals fa referència a la visió expressionista de l'estètica musical, i és defensat, entre d'altres, per Susanne Langer (1895-1985). Per als expressionistes - igual que per als referencialistes - la música és un mitjà capaç de transmetre sentiments. Vegem com Langer (1966: 6) defineix l'obra d'art (traducció de l'anglès original):

Art, en el sentit aquí al·ludit —és a dir, el terme genèric que inclou pintura, escultura, arquitectura, música, dansa, literatura, teatre i cinema - pot ser definit com la pràctica de crear formes perceptibles de l'expressió de sentiments humans. Dic formes "perceptibles", més que "sensuals", perquè algunes obres d'art estan destinades a la imaginació, més que als sentits externs.

Però la comunicació i l'expressió s'articulen d'una manera notablement diferent al llenguatge referencial. L'autora defensa que el procés comunicatiu no es produeix mitjançant una referència convencional, ja que la música manca d'estructura gramatical i, per tant, no s'assembla en absolut al llenguatge comú. «En consecuencia, Langer rechaza el análisis como método para la comprensión de la música, desvincula la semanticidad de la música de su capacidad para referirse a objetos y niega la posibilidad de traducir la música al lenguaje convencional» (Marrades Millet, 2000). Considera la música com un símbol de la vida emocional, capaç de revelar emocions. Per tant, hi ha una analogia lògica entre la música i les emocions, però la idea de la naturalesa veritable de la música, la significació de la qual es dóna de forma immediata, lliure d'un pensament verbalitzat, reforça que aquesta analogia es produïsca sense necessitat d'una sèrie de convencionalismes. Per tant, desvincula la referencialitat de la música a objectes o sentiments base d'un patró sintàctic històricament construït i après (Green, 2008: 169-170). En el seu tractat Sentimiento y forma, Langer ofereix una visió clara de la naturalesa de l'expressió en la música. Des d'una perspectiva centrada en el sentiment, l'autora marca la clara diferència entre la seua tesi i el pensament referencialista (Langer, 1967: 36).

Nuestro interés en la música surge de su íntima relación con la importantísima vida del sentimiento, sea cual fuere esta relación. Después de mucho debatir las teorías en boga, la conclusión alcanzada en Nueva clave de la filosofía es que la función de la música no es la estimulación del sentimiento, sino su expresión; y más aún, no la expresión sintomática de los sentimientos que acosan al compositor, sino una expresión simbólica de las formas de la sensibilidad tal como él las comprende. Expresa lo que imagina de los sentimientos más que su propio estado emocional, y expresa lo que él sabe acerca de la llamada "vida interior"; lo que puede exceder su caso personal, porque música es para él una forma simbólica a través de la cual puede aprender así como también expresar ideas sobre la sensibilidad humana.

Hay muchas dificultades implícitas en el supuesto de que la música es un símbolo, porque estamos tan hondamente impresionados por el modelo de la forma simbólica, a saber, el 
lenguaje, que con toda naturalidad trasponemos sus características a nuestras concepciones y expectaciones de cualquier modo. Con todo, la música no es una clase de lenguaje. Su significado es en verdad algo diferente de lo que tradicional y propiamente se llama "significado". Quizá los lógicos y los filósofos positivistas que se han opuesto al término "significado implícito", a partir de que la base de que el "significado" propiamente dicho es siempre explicable, definible y traducible, estén impulsados por el deseo perfectamente racional de mantener tan difícil término libre de complicaciones ulteriores y de fuentes de confusión; y si esto puede hacerse sin excluir el concepto mismo que yo designo como "significado implícito", parece del todo sensato aceptar sus observaciones críticas.

Per citar un exemple, Langer no dóna suport a la necessitat que en ocasions tenen mestres, crítics o fins i tot compositors musicals de convertir cert discurs musical en música programàtica. Segons Langer, un programa és una manera d'encasellar, d'avançar amb una crossa o un suport, el discurs musical, assumint que l'oient no és suficientment musical com per a pensar en termes musicals, mentre es retenen els sentiments de la imaginació i es neguen, com ja hem dit, la veritable naturalesa de la música, sense convenció i lliure de verbalització (Langer, 1957: 196-197).

Aquests tres corrents de pensament ofereixen diferents mirades sobre el que es transmet a través de l'experiència musical. Tot i que cap d'elles pot explicar de manera inequívoca els mecanismes a través dels quals es produeix la comunicació en la música, les perspectives mostren visions sobre l'experiència musical que, en compte de considerar-se excloents, es poden articular com complementàries. L'experiència musical no és un procés mecànic que segueix la directriu d'un patró comunicatiu i emocional determinat. Qualsevol intent de simplificar la vivència musical en un receptari de respostes determinades, tot i contenir informació de gran interès sobre la música i la seua recepció, oferirà sempre una visió limitada o esbiaixada dels processos musicals, com també de la complexitat de les persones en la seua capacitat de reacció davant del fet musical.

Però tant Hanslick, Cooker com Langer entenen el fet musical com un fenomen a través del qual les persones ens comuniquem. La música té una significació i això li concedeix un valor indiscutible en la dimensió comunicativa de les persones. «Después del habla, la música es el sonido más importante generado por el ser humano. Es una estructuración de sonidos que constituye un lenguaje imaginario con un valor expresivo propio» (Hormigos Ruiz, 2008: 175). És probablement per aquesta raó per la qual la música persisteix en totes les cultures i és una part important del procés educatiu de les persones. No únicament perquè és un tipus de so agradable ni, fins i tot, perquè és capaç de facilitar l'experiència estètica, sinó perquè és una forma simbòlica. «La música és un discurs tan antic com l'espècie humana, un mitjà a través del qual s'articulen, en formes sonores, idees sobre nosaltres mateixos i sobre els altres» (Swanwick, 1999: 2).

\section{La construcció social del significat musical}

Aquest apartat pretén articular les teories al voltant del significat i de l'afecte en l'experiència musical, que fins a aquest moment han estat abordades des de les perspectives més formals o mecanicistes de l'expressió musical, per tal d'incorporar la influència del 
context social en matèria musical, fins ara pràcticament oblidada. Finalment, en parlar de significat musical, la influència del context social resideix en l'origen més primitiu de l'experiència musical, ja que la mera distinció entre soroll i música té el seu fonament en consideracions que poden formar part de la dimensió social de les persones.

Efectivament, l'origen de l'experiència musical té un component de naturalesa social. Per això, la música pot i ha de ser analitzada des d'una perspectiva que considere el context social i cultural en què té cabuda. En primer lloc, perquè l'activitat musical és una activitat eminentment humana; per tant, la música, en considerar-se una pràctica social, és susceptible de considerar-se com a objecte d'escrutini sociològic (Martin, 1995: 14; Ramírez Hurtado, 2006: 69; Swanwick, 2006: 6).

Com a activitat essencialment humana - a més de ser única i exclusiva de l'espècie humana- la música és social. Així mateix, no és una activitat que ocasionalment es done en el marc d'algunes societats determinades, sinó que «totes les cultures i societats que fins ara coneixem tenen una música pròpia» (Elliott, 1989: 11; Green, 2003: 263). Aquesta afirmació no pretén altra cosa que destacar que la música resideix en els havers culturals de cada societat, i que la necessitat d'expressar-se a través d'una o d'altra forma musical es dóna en tota societat coneguda fins ara. Com Eugenio Trías (2008: 102) afirma: «Hay culturas musicales siempre y ahí donde hay cultura. La música acompaña al hombre desde que es hombre». Per tant, concordem amb Swanwick (2006: 6) quan, en al-ludir a l'activitat musical, descriu els productes que són conseqüència de la mateixa com a propis de qualsevol entitat cultural. D'aquesta manera,

[...] los productos musicales son una prueba de la necesidad que siente cada individuo de crear e interpretar el mundo mediante unos procesos simbólicos compartidos. Esta necesidad biológica y psicológica trasciende la raza, la nacionalidad y las tendencias culturales. En esta empresa específicamente humana, la música - como una de las grandes formas simbólicasdesempeña su papel.

Swanwick (1999: xii) argumenta així mateix que la major part de les persones en la majoria de les cultures comparteixen aquesta propensió a la música — de la mateixa forma que comparteixen també la propensió al llenguatge-, i denoten que aquesta propensió existeix, tot i les diferències musicals i la funció social de la música que es donen arran de les pròpies diferències personals i culturals.

Però en afirmar que totes les cultures i societats fins ara conegudes posseeixen una determinada música podríem pretendre demostrar que la música és un fenomen universal. L'existència d'un món sonor de determinades característiques en cadascuna de les societats que es configuren com una realitat cultural subratlla la importància de la música entre els sabers i els valors de cada forma d'organització de les persones. La música, des d'aquest punt de vista, es converteix en un tret fonamental en el reconeixement d'una identitat cultural, per a aquell que contempla una determinada realitat social des de fora. Podem doncs construir un imaginari que ens permeta identificar i caracteritzar una cultura a través dels seus trets musicals. D’aquesta forma, la música es converteix en un fenomen de diferenciació entre les persones i que els diferents col-lectius adapten com un element propi de la identitat de la realitat cultural i de cadascun dels seus membres. La música, 
des d'aquesta perspectiva, té la capacitat tant d'unir les persones com de diferenciar-les (Elliott, 1989: 12).

No obstant això, el fet que fer música siga una característica universal de totes les societats no vol dir que siga compartida per tots els membres de la societat (Green, 2003: 263). No tots els membres d'una societat prenen necessàriament part en la vida musical ni en el procés de producció i distribució de les seues músiques en cada context. Tampoc la vivència, l'entesa i el gaudi de la música són fenòmens que formen naturalment part de la nostra condició com a subjectes; per contra, són processos enterament apresos. Els éssers humans no necessàriament entenem, apreciem, gaudim o compartim d'una manera innata i immediata músiques que provenen de realitats culturals que ens són completament alienes. Per aquesta raó, «no podem afirmar que la música és un llenguatge universal» (Elliott, 1989: 11).

Per tant, necessitem un procés d'aprenentatge mitjançant el qual obtenim la capacitat de caracteritzar un determinat fenomen sonor com música - què es considera com a música. És així, a través d'aquest procés d'aprenentatge, que en la majoria dels casos respon a un episodi d'enculturació, com adquirim les destreses per a codificar i posteriorment entendre els diferents significats que la música pot fer emergir en l'individu. Per aquest motiu, com Green (2005: 78) indica, per tal que un oient reconega la música com a música, o entenga una concatenació de sons en particular com un discurs musical, ha d'estar immers en un complex entramat de convencions socials. Aquestes convencions determinaran no només l'organització i significació que l'oient donarà als sons, sinó també els significats dels contextos socials que envolten la producció, distribució i recepció d'aquesta música.

\section{Consideracions finals}

Conscientment o inconscientment, la producció musical s'allunya, en la nostra cultura occidental, de la quotidianitat dels individus, però la distribució i, sobretot, la recepció musical estan pràcticament presents en tots els membres de la nostra societat. Avui en dia, la música il·lustra gran part de les nostres activitats quotidianes. Fins i tot l'activitat específica d'audició de música per se ha estat, en la majoria de les ocasions, substituïda o iniciada per una escolta musical associada a una imatge determinada. La recepció musical en la nostra societat actual es produeix generalment, de manera més immediata, a través d'un mitjà audiovisual, en particular la televisió i el cinema; un mitjà digital, principalment en les pàgines d'internet; o associat a activitats quotidianes, lúdiques o de consum, en magatzems, botigues, gimnasos, discoteques, etc. Per això, els espais naturals de distribució musical, a diferència dels d'antany, ja no es concentren en les sales de concerts. Si bé la sala de concerts continua sent un mitjà a través del qual es distribueixen determinades músiques, contempla únicament la difusió i recepció de músiques molt específiques.

L'auge en els processos de distribució fruit d'aquests avenços tecnològics ha afavorit que la música arribe a tots els estrats de la societat i que la recepció d'una gran diversitat musical es convertisca en un fet quotidià per a la major part de la població. Això afavoreix que l'obra musical estiga sotmesa a un judici ampli i, en principi, que concorde amb les característiques de la societat en la qual és produïda. La música pretén, en major mesura, 
ser difosa i, per tant, tracta d'apropar-se a un espectre ampli de la societat. L'altra cara de la moneda és la transformació de l'art, en particular de la música, en una mercaderia subjecta a les lleis de mercat de cada societat en particular (Hormigos Ruiz, 2008: 120). Alguns autors han criticat amb vehemència la capacitat que la indústria ha mostrat d'influir, de regir i de modificar els gustos musicals d'una determinada societat a partir d'interessos econòmics (Bourdieu, 2000: 159).

La exaltación de los artistas del pasado guarda relación con la aparición de una cultura musical basada en el disco, más que en la práctica de un instrumento y en la asistencia asidua a conciertos, y en la banalización de la perfección instrumental que imponen la industria del disco y la competencia inseparablemente económica y cultural entre los artistas y los productores.

Fins i tot aquest aparell de construcció i dinamització dels gustos musicals en la societat en funció d'interessos industrials ha portat els sociòlegs a plantejar-se qüestions sobre el rol dels gustos musicals en referència a la construcció de diferències socials. Qüestions en matèria de gust musical com a mecanisme d'exclusió social són sovint portades a debat (DeNora, 2003: 167).

Sens dubte, aquesta creixent activitat de distribució musical ha aportat a la societat l'increment dels estils i subestils musicals que estan presents diàriament en les nostres vides. L'augment en la producció musical, la difusió de músiques d'altres cultures, la influència de la mateixa societat en les activitats musicals, la pluralitat estilística, etc., suposen necessàriament una contínua redefinició dels significats musicals.

Efectivament, des d'aquesta perspectiva, el significat en matèria musical és creat en els processos d'interacció social que configuren la nostra experiència del món en general. És a partir d'aquesta experiència prèvia com s'entrellacen significats amb patrons sònics (Martin, 1995: 63).

Això no ha d'oblidar de cap manera l'experiència prèvia, individual o social, per a la construcció i per a la redefinició dels significats musicals i, per tant, necessàriament al·ludeix de nou a la incidència social en aquesta significació. Atès que l'experiència prèvia comporta el sediment d'un residu que, conscientment o inconscientment, incidirà en futures representacions o situacions. Aquests esquemes d'experiències passades són fonamentals per a la significació de nous moviments, pensaments o sentiments que s'esdevenen en el nostre context i que referenciaran i articularan experiències futures semblants (Swanwick, 1999: 20).

No obstant això, en l'experiència musical, els processos de significació individuals i col·lectius se succeeixen i s'organitzen condicionant la resposta que cada persona obté d'un determinat estímul musical. Per tot això, la dimensió relacional de l'ésser humà és clau per a entendre tot procés musical a què es faça al·lusió. És des d'aquest punt de vista on la música passa a formar part rellevant de la dimensió ideològica de les societats, com també de la construcció identitària de persones i de pobles. Si la sociologia de la música oblida la influència d'aquesta construcció social en matèria de significació musical, obviarà una de les característiques més importants i determinants en la definició d'aquests significats. 


\title{
BIBLIOGRAFIA
}

Bourdieu, P. (2000): Cuestiones de sociología, Madrid, Istmo.

Cooke, D. (1959): The Language of Music, Oxford, Oxford University Press.

Copland, A. (1988): Cómo escuchar la música, Mèxic, Fondo de Cultura Económica.

DeNora, T. (2003): «Music sociology: getting the music into the action», British Journal of Music Education, 20 (2), 165-177.

ELLIOTt, D.J. (1989): Key concepts in multicultural music education, International Journal of Music Education, 13(1), 11-18.

Fischer, E. (2001): La necesidad del arte, Barcelona, Península.

Green, L. (2003): «Music Education, Cultural Capital, and Social Group Identity», en Clayton, M. i altres (eds.): The cultural study of music: a critical introduction, Nova York, Routledge, 263-283.

- (2005): «Musical Meaning and Social Reproduction: A Case for Retrieving Autonomy», Educational Philosophy and Theory, 37 (1), 77-92.

- (2008): Music on Deaf Ears: Musical Meaning, Ideology and Education, Bury St Edmunds, Arima.

Hanslick, E. (1957): The beautiful in music, Nova York, Liberal Arts Press.

Hormigos Ruiz, J. (2008): Música y sociedad. Análisis sociológico de la cultura musical de la posmodernidad, Madrid, Fundación Autor.

LANGER, S.K. (1957): Philosophy in a new key: A study in the symbolism of reason, rite, and art, Cambridge, Massachusetts, Harvard University Press.

- (1966): «The cultural importance of the arts», Journal of Aesthetic Education, 1 (1), 5-12.

- (1967): Sentimiento y forma, Mèxic, Centro de Estudios Filosóficos, Universidad Nacional Autónoma de México.

Malbrán, S. (1997): «Música y metaudición: Algunas reflexiones para su estudio», Orphetron, 2, 40-46.

Marrades Millet, J. (2000): «Música y significado», Teorema, xix (1), 5-25.

Martí I Pérez, J. (2000): Más allá del arte. La música como generadora de realidades sociales, Barcelona, Deriva.

Martin, P.J. (1995): Sounds and society: Themes in the sociology of music, Manchester, Manchester University Press.

Meyer, L.B. (2001): La emoción y el significado en la música, Madrid, Alianza Música.

Ramírez Hurtado, C. (2006): Lenguaje y educación. La comunicación humana a través de la música en el proceso educativo, València, Tirant Lo Blanch.

Stravinski, I. (2006): Poética musical, Barcelona, Acantilado.

SwAnwick, K. (1999): Teaching music musically, Londres, Routledge.

- (2001): A Basis for Music Education, Oxon, Routledge.

- (2006): Música, pensamiento y educación, Madrid, Ministerio de Educación y Ciencia, Ediciones Morata.

TRíAS, E. (2008): «El canto de las sirenas», EN-CLAVES del pensamiento, II (4), 101-111.

\section{BIONOTA}

\begin{abstract}
Albert Cabedo Mas
Professor de l'Àrea de Música del Departament d'Educació de la Universitat Jaume I. Va obtindre el títol Superior de Música, especialitat de Violí, al Conservatori Superior de Música "Salvador Seguí" de Castelló i el Màster en Música per l'Acadèmia Estoniana de Música i Teatre, a Tallin. Posteriorment va cursar el Màster en Estudis de Pau, Conflictes i Desenvolupament a la Universitat Jaume I. En aquesta mateixa Universitat va obtindre el seu doctorat. Té diverses publicacions en revistes científiques tant nacionals com internacionals. Els seus interessos d'investigació inclouen l'educació musical, el patrimoni musical, la convivència, la interculturalitat i el procés de transmissió musical al si de les cultures.
\end{abstract}

